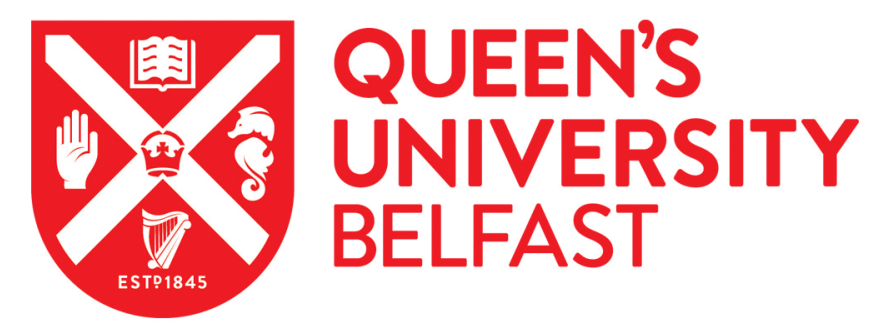

\title{
Bystander Signalling: Exploring Clinical Relevance Through New Approaches and New Models
}

Butterworth, K. T., McMahon, S. J., Hounsell, A. R., O'Sullivan, J. M., \& Prise, K. M. (2013). Bystander

Signalling: Exploring Clinical Relevance Through New Approaches and New Models. Clinical Oncology, 25(10), 586-592. https://doi.org/10.1016/j.clon.2013.06.005

Published in:
Clinical Oncology

Document Version:

Peer reviewed version

Queen's University Belfast - Research Portal:

Link to publication record in Queen's University Belfast Research Portal

Publisher rights

(c) 2013 Elsevier Ltd. This manuscript version is made available under the CC-BY-NC-ND 4.0 license http://creativecommons.org/licenses/by$\mathrm{nc}-\mathrm{nd} / 4.0 /$, which permits distribution and reproduction for non-commercial purposes, provided the author and source are cited.

\section{General rights}

Copyright for the publications made accessible via the Queen's University Belfast Research Portal is retained by the author(s) and / or other copyright owners and it is a condition of accessing these publications that users recognise and abide by the legal requirements associated with these rights.

Take down policy

The Research Portal is Queen's institutional repository that provides access to Queen's research output. Every effort has been made to ensure that content in the Research Portal does not infringe any person's rights, or applicable UK laws. If you discover content in the Research Portal that you believe breaches copyright or violates any law, please contact openaccess@qub.ac.uk. 


\section{Bystander signalling: Exploring clinical relevance through new approaches and new models}

K.T. Butterworth ${ }^{1}$, S.J. McMahon ${ }^{1}$ A.R. Hounsell ${ }^{1,2}$, J.M. O’Sullivan ${ }^{1,3}$ and K.M. Prise ${ }^{1}$

${ }^{1}$ Centre for Cancer Research and Cell Biology, Queen’s University Belfast, Belfast, Northern Ireland, United Kingdom; ${ }^{2}$ Radiotherapy Physics, Northern Ireland Cancer Centre, Belfast Health and Social Care Trust, Belfast, Northern Ireland, United Kingdom; ${ }^{3}$ Clinical Oncology, Northern Ireland Cancer Centre, Belfast Health and Social Care Trust, Belfast, Northern Ireland, United Kingdom

\section{Corresponding author}

Prof Kevin Prise

Centre for Cancer Research and Cell Biology

Queen’s University Belfast

97 Lisburn Road

Belfast

BT9 7BL

Northern Ireland

United Kingdom

Tel: 02890972934

Fax: 02890972776

Email: k.prise@qub.ac.uk

Word count: 2593

Number of tables: 3

Number of figures: 2 


\begin{abstract}
Classical radiation biology research has centred on nuclear DNA as the main target of radiation induced damage. Over the past two decades, this has been challenged by a significant amount of scientific evidence clearly demonstrating radiation induced cell signalling effects to have important roles in mediating overall radiobiological response. These effects, generally termed radiation induced bystander effects (RIBEs) have challenged the traditional DNA targeted theory in radiation biology and highlighted an important role for cells not directly traversed by radiation. The multiplicity of experimental systems and exposure conditions in which RIBEs have been observed has hindered precise definitions of these effects. However, RIBEs have recently been classified for different relevant human radiation exposure scenarios in attempt to clarify their role in vivo. Despite significant research effort in this area, there is little direct evidence for their role for in clinically relevant exposure scenarios. In this review, we explore the clinical relevance of RIBEs from classical experimental approaches through to novel models that have been used to further determine their potential implications in vivo.
\end{abstract}

\title{
Key words
}

bystander effect, in vivo, ionising radiation, microbeam

\section{Searches}

Articles cited in this manuscript were sourced through a literature search on the Medline/Pubmed database using the search terms 'radiation', bystander' 'in vivo' and 'microbeam'. Full articles were retrieved when the abstract was deemed relevant. The bibliographies of retrieved papers were also searched and relevant articles included.

\section{Conflict of Interest}

The authors have no conflict of interest to declare. 


\section{Introduction}

Ionising radiation (IR) is an effective cancer therapy due to its ability to induce cell death as a consequence of DNA damage resulting from energy deposition in the cellular environment. Most cellular responses to IR are mediated through direct energy deposition in the DNA or indirectly through reactive oxygen species (ROS) and other free radicals formed due to the radiolysis of water (1).

Classically, radiation biology research has focussed on nuclear DNA as the sole target of radiation induced damage. However, over the last 25 years a large body of scientific evidence has challenged the view that radiobiological responses occur only in cells directly targeted by radiation as biological effects have been shown to occur outside of the radiation target. These "Non-targeted effects" include genomic instability and several radiation induced signalling effects (2), generally termed radiation induced bystander effects (RIBEs). RIBEs were first identified by Nagasawa and Little (3) who observed chromosome damage in the form of sister chromatid exchanges in more than $30 \%$ of a cell population under conditions in which only $1 \%$ of cell nuclei had been targeted using $\alpha$-particles. Since then, RIBEs have been demonstrated using a range of experimental systems with multiple biological endpoints. Despite increasing evidence in a growing number of model systems, the implications of RIBEs for radiotherapy and cancer risk remain to be fully determined. In this review, we describe RIBEs in the context of current experimental and clinical exposure scenarios and consider potential implications for cancer risk and radiotherapy.

\section{Discussion}

\section{Defining RIBEs}

In general terms, RIBEs may be defined as radiobiological responses observed in cellular systems which have not been directly traversed by ionising radiation but are in close proximity to irradiated cells. These effects are cell signal mediated either through direct physical cell contact via gap junction intercellular communication (GJIC) (4) or through secreted, diffusible signalling molecules into the surrounding media (5-7). A number of candidate signalling molecules have been identified in 
mediating RIBEs such as reactive oxygen and nitrogen species (ROS/NOS) including nitric oxide (NO), and cytokines such as transforming growth factor- $\beta$ (TGF- $\beta$ ) and interleukin-8 (IL-8). These have been shown to initiate multiple downstream signalling pathways including the mitogen activated

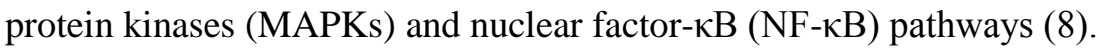

Although RIBEs can be considered primarily as signalling mediated effects, precise definitions have remained difficult as effects are often dependent on the experimental system or exposure conditions being measured. The caveats associated with these different effects observed under different experimental and exposure conditions were the subject of recent review by Blyth and Sykes (9) who stated that 'most reports in the literature are accompanied by the authors own definition, usually framed in the context of the data presented in that report'. This is an important consideration which the authors addressed by attempting to establish a general framework for the classification radiation induced signalling effects based on human radiation exposure scenarios. They define three different categories; bystander effects, cohort effects and abscopal effects.

The most well-established of these classes are abscopal effects. These are defined as radiation induced effects in unirradiated tissues occurring outside of an irradiated volume. Radiation induced abscopal effects were observed more than 60 years ago in some patients following radiotherapy and do not appear to be dose dependent dose making them particularly relevant to the partial body exposures typically delivered during conformal radiotherapy. Abscopal effects are rarely recognised in the clinic and so their importance in radiotherapy response remains controversial (10).

More recently, bystander effects have been defined for human exposure scenarios as radiation induced, signal mediated effects in unirradiated cells within an irradiated volume exposed to a sufficiently low dose that a portion of cells within the exposed volume remain unexposed and survive. These effects are relevant for whole and partial body exposures to very low doses, such as those from background radiation, high altitude flights and ingested radioactive potassium.

A third classification of effects, termed cohort effects describe the component of overall radiobiological response in irradiated cells which is not a consequence of direct energy deposition in 
the target cell but rather due to communication between cells within an irradiated volume. Cohort effects are relevant for any exposures where the majority of a cell population is exposed to significant dose and whilst this interpretation is relatively uncommon in the literature, there is increasing evidence that intercellular signalling plays a role in overall radiation response.

These classifications of radiation induced signalling are shown schematically in figure 1. Distinction between the classifications is difficult in modern radiotherapy as patients are exposed to complex field geometries with steep dose gradients resulting in delivery of differential doses to cells in close proximity which can freely signal to one another. Whilst these effects are typically classified and studied separately, they have many common characteristics in that they all occur in response to radiation exposure, are mediated by extracellular signalling factors and cause negative radiobiological effects in neighbouring cells.

Consequently, many of these experimentally and clinically observed phenomena which are often classified as different effects actually stem from the same or similar cellular signalling origin and may be interpreted as different consequences of the same generalised RIBEs. As a result, there is significant opportunity for novel approaches to investigate these effects in more clinically relevant scenarios.

\section{Classical experimental approaches for studying RIBEs}

A diverse range of experimental approaches have been used to investigate RIBEs at the single cell, multicellular and whole organism levels. A selection of these studies in single cells is summarised in Table 1 and the various approaches used shown schematically in figure 2. Classical in vitro studies used polonium needles (11) or low fluence $\alpha$-particle exposures (12) to target a small number of cells within a population. Technological developments have driven more sophisticated approaches using radiation microbeams allowing the delivery of highly focussed low energy micron sized radiation beams to single cells or subcellular targets. They have been successfully used as mechanistic probes

to investigate biological processes including kinetics of DNA damage repair and subcellular 
signalling processes involved in RIBEs (13). Microbeam approaches have utilised not only ion beams, including protons and helium ions, but focussed soft X-ray microbeams and electron microbeams.

In addition to microbeam studies, several cell culture methods have been applied to study RIBEs. These have involved the transfer of culture medium from irradiated cells onto unirradiated recipient cells known as media transfer $(14,15)$ or co-culturing methods where irradiated and unirradiated cell populations are physically separated but free to signal to one another (6). These techniques have been used to demonstrate RIBEs manifested in a range of biological endpoints including DNA damage $(4,16)$, cellular transformation (17), changes in gene expression (18), chromosomal aberrations $(3,19,20)$ and mutations (21).

Whilst these early experimental approaches have provided significant understanding of the signalling mechanisms and kinetics of RIBEs, in most cases, they do not accurately represent the physiological multicellular environment or radiation dose distributions delivered during clinical treatment protocols. This has led to the development of new approaches to investigate RIBEs under more clinically relevant exposure conditions and at the multicellular and whole organism levels.

\section{New experimental approaches for studying RIBEs}

Early approaches to investigate RIBEs fail to accurately replicate clinically relevant exposure scenarios in respect to beam energy, delivery time and dose distributions. This has recently been addressed in several studies which have delivered modulated $6 \mathrm{MV}$ radiation fields using clinical linear accelerators to more accurately replicate exposure conditions in vivo $(7,23,24)$. Work from our laboratory determined cell survival responses occurring in- and out-of-field using a modulated beam profile generated using a multi leaf collimator (MLC) and demonstrated significantly reduced out-offield cell survival following irradiation compared to the level of response predicted on scattered dose alone (7). In addition, the observed out-of-field responses were shown to be dependent on cell signalling between the differentially irradiated cell populations in part mediated by nitric oxide. Whilst these studies have provided evidence for RIBEs in response to more clinically relevant 
radiation exposures at high dose using MV energy, cell culture models are limited to two dimensions, lacking cellular architecture and physiological context.

Several multicellular tissue models summarised in table 2, have been used to investigate RIBEs ex vivo using sections of porcine ureter $(26,27)$ and reconstructed 3D skin models $(28,29)$. Recently, Sheridan et al, (31) observed RIBEs manifest as elevated DNA damage in nonadjacent colon tissue obtained from patients receiving post neoadjuvant radiotherapy.

At the whole organism level, RIBEs have been observed in a number of systems for different exposure scenarios (32). These are summarised in table 3. The first in vivo evidence of RIBEs was provided by the identification of cell damaging or clastogenic factors in the serum of irradiated patients which when transferred onto cultures of unirradiated lymphocytes showed cell damaging activity $(33,34)$. As in more simplistic cell models, it is difficult to distinguish between types of radiation induced signalling in vivo. Most experimental models have involved partial body exposures and are therefore classified as abscopal effects. These have been observed clinically for many years and were originally defined as systemic radiation effects following local radiotherapy (35).

Experimentally, abscopal effects have been demonstrated in a number of whole organisms, summarised in table 3. Using the C57BL/6 mouse, Camphausen et al, (36) showed significant reduction in the growth of tumours implanted to the dorsal midline when the legs of the animals were irradiated. In the same model, Koturbash et al, (37) showed induction of DNA damage in skin tissue up to $7 \mathrm{~mm}$ away from the irradiated site following partial body exposure.

An important model which has been used to demonstrate the tumourigenic potential of abscopal effects is the Patched-1 $\left(\right.$ Ptch $\left.^{+/}\right)$mouse $(41,42)$. PTCH is a Sonic Hedgehog (SHH) receptor and negative regulator of the pathway causing predisposition to childhood medulloblastoma (43). Ptch1 $1^{+/}$ mutant mice develop cerebellar tumours resembling human medulloblastoma which is accelerated when irradiated as neonates (44). Partial body irradiation of neonatal Ptch1 ${ }^{+/}$mice was shown to significantly increase the occurrence of medulloblastoma compared to control animals, accompanied with increased DNA damage and apoptosis in the cerebellum. 
In addition to partial body exposures, other approaches have involved bone marrow transplantations in which irradiated bone marrow cells differentiated from unirradiated bone marrow cells using cytogenetic markers, are capable of inducing genetic instability in the progeny of unirradiated bone marrow cells (38).

In vivo demonstration of RIBEs has not been exclusively limited to mouse models. In Sprague Dawley rats, partial irradiation of the lower lung has been shown to cause increase damage in the upper out-of-field regions of the lung $(45,46)$. Mothersill and colleagues have used several species of fish including rainbow trout (47), zebrafish (48) and medaka (49) to demonstrate RIBEs in vivo.

Although RIBEs have clearly been demonstrated in vivo, the systems in which they have been investigated do not accurately replicate typical exposure conditions during radiotherapy. Whilst next generation higher energy microbeams will provide improved subcellular targeting accompanied with advanced imaging, there is a need to determine RIBEs under conditions analogous to clinical protocols. This is potentially possible through the application of tumour bearing animals models in combination with advanced small animal radiation research platforms (52) and presents an exciting opportunity to determine the precise implications of RIBEs for radiotherapy and cancer risk following clinically relevant exposures.

\section{Predictive models of RIBEs}

To fully determine the implications of RIBEs in the clinical context, several attempts to describe predictive frameworks of radiation induced cell signalling have been proposed (53-61). Generally, these models tend to describe cellular responses to ionising radiation as resulting from two distinct components - a "direct" component, due to radiation interactions within a particular cell, and an “indirect” component resulting from intercellular communication, which is dependent on the exposure across the entire cellular population.

One of the primary areas for disagreement between these different models is the case where cells are subject to both direct and indirect effects, determining how they interact and which effects are dominant under which conditions. Many older models, based on media transfer or co-culture 
experiments suggested that indirect components are small compared to the direct component, or even mutually exclusive with direct exposures. However, more recent work such as that of Ebert et al, (60) and McMahon et al, (61) suggest that indirect effects may play a significant role not only in out-offield bystander cells, but also on the survival of cells within an irradiated population at high doses, reflecting the significance of intercellular communication in cohort effects, as outlined above. These results may have significant implications for the interpretation of a large portion of radiobiology data as they suggest the traditional paradigm of independent cellular responses may not be valid, with further consequences for the evaluation of many clinical conditions.

\section{Implications for radiotherapy and cancer risk}

From our understanding of RIBEs and increasing evidence of their role in vivo, it is clear that radiation induced signalling is of significant importance in responses to radiotherapy. From the clinical perspective RIBEs have a number of important potential implications particularly relating to tumour control, normal tissue response and risk of secondary cancer.

Whilst classically defined bystander effects were interpreted as a low dose phenomenon, recent findings have highlighted the potential significance of radiation induced signalling in cohort and bystander effects following modulated dose distributions suggesting these may have a role in directly irradiated regions $(7,23,24)$. Signalling from cells irradiated to high doses within the planning target volume (PTV) may contribute to increased tumour cell killing and improved outcomes. Validation of such effects is likely to have significant impact on clinical decisions particularly at tumour margins as it is currently suggested that the optimal planning solution should incorporate a 'biological' margin to ensure the irradiation of some healthy tissue.

In the absence of an accurate estimate of the spatial component of radiation induced signalling, it is difficult to define the role of RIBEs in normal tissue. Potentially, RIBEs may have a negative impact in normal tissue due to the signalling extending beyond the physical dose distributions of conventional treatment plans. This would mitigate the anticipated reduction in radiation toxicity achieved with more conformal dose distributions to the tumour target. 
As a result of these effects, definitions of PTV based on physical dose constraints may not accurately describe biologically effective dose mediated through cell signalling. Current tumour control probability (TCP) and normal tissue complication probability (NTCP) models could be significantly enhanced by the input of biological parameters to account for spatial dose distributions and biological response. An example of this would be in dose-painting scenarios e.g. where dose is boosted into discrete regions of the tumour based on biological activity (62).

The role of RIBEs on secondary cancer risk has been considered for some time in relation to low dose environmental exposures and out-of-field regions in radiotherapy $(63,64)$. Attempts to attribute additional cancer risk to these effects have remained challenging as current empirical models of secondary cancer risk do not address specific mechanisms such as in vivo signalling effects.

In addition, further understanding of the underlying molecular mechanisms mediating RIBEs may identify novel therapeutic targets enabling the exploitation of cell signalling mechanisms to improve the specificity of radiotherapy treatment by sparing healthy tissues which lie close to radiation field.

Taken together it is clear that the radiation induced signalling effects demonstrated at the single-, multi-cellular and whole organism level are likely to have important radiobiological consequences for clinical exposures. Further understanding of these effects gained through the application of new models and new technologies including precision image-guided in vivo radiobiology is likely to provide opportunities to improve the efficacy of radiotherapy through biologically optimised treatment planning and novel therapeutic targets.

\section{Acknowledgements}

The authors are grateful to Cancer Research UK (C1513/A7047 KMP and C212/A11342 SMM/ARH), Breast Cancer Campaign (2009MayPR03), UK Department of Health (091/0205), the European Commission (EPIRADBIO project No 269553) and the Friends of the Cancer Centre, for funding their work. 


\section{References}

1. E. J. Hall, A. J. Giaccia, Radiobiology for the Radiologist, $7^{\text {th }}$ edition. Philadelphia PA, Lippincott, Williams and Wilkins, 2011.

2. Kadhim M, Salomaa S, Wright E, Hildebrandt G, Belyakov OV, Prise KM, Little MP. Nontargeted effects of ionising radiation-Implications for low dose risk. Mutat Res. 2012;5742(12).

3. Nagasawa H, Little JB. Induction of sister chromatid exchanges by extremely low doses of alphaparticles. Cancer Res 1992;52 (22):6394-6.

4. Azzam EI, de Toledo SM, Little JB. Direct evidence for the participation of gap junctionmediated intercellular communication in the transmission of damage signals from alpha -particle irradiated to nonirradiated cells. Proc Natl Acad Sci U S A 2001;98(2):473-8.

5. Mothersill C, Seymour CB.Cell-cell contact during gamma irradiation is not required to induce a bystander effect in normal human keratinocytes: evidence for release during irradiation of a signal controlling survival into the medium. Radiat Res 1998;149(3):256-62.

6. Yang H, Anzenberg V, Held KD. The time dependence of bystander responses induced by ironion radiation in normal human skin fibroblasts. Radiat Res 2007;168(3):292-8.

7. Butterworth KT, McGarry CK, Trainor C et al. Out-of-field cell survival following exposure to intensity-modulated radiation fields. Int J Radiat Oncol Biol Phys 2001;79 (5):1516-22.

8. Prise KM, O'Sullivan JM. Radiation-induced bystander signalling in cancer therapy. Nat Rev Cancer 2009;9(5):351-60.

9. Blyth BJ, Sykes PJ. Radiation-induced bystander effects: what are they, and how relevant are they to human radiation exposures? Radiat Res 2011;176(2):139-57.

10. Kaminski JE, Shinohara E, Summers JB, Niermann KJ, Morimoto A, Brousal J. The controversial abscopal effect. Cancer Treat Rev 2005;31(3):159-72. 
11. Zirkle RE, Bloom W. Irradiation of parts of individual cells. Science 1953;117(3045):487-93.

12. Miller RC, Randers-Pehrson G, Geard CR, Hall EJ, Brenner DJ. The oncogenic transforming potential of the passage of single alpha particles through mammalian cell nuclei.Proc Natl Acad Sci U S A 1999;96(1):19-22.

13. Schettino G, Al Rashid ST, Prise KM. Radiation microbeams as spatial and temporal probes of subcellular and tissue response. Mutat Res 2010;704(1-3):68-77.

14. Mothersill C, Seymour C. Medium from irradiated human epithelial cells but not human fibroblasts reduces the clonogenic survival of unirradiated cells. Int J Radiat Biol 1997;71(4):4217.

15. Lyng FM, Seymour CB, Mothersill C. Initiation of apoptosis in cells exposed to medium from the progeny of irradiated cells: a possible mechanism for bystander-induced genomic instability? Radiat Res 2002;157(4):365-70.

16. Little JB, Nagasawa H, Li GC, Chen DJ. Involvement of the nonhomologous end joining DNA repair pathway in the bystander effect for chromosomal aberrations. Radiat Res. 2003 Feb;159(2):262-7.

17. Sawant SG, Randers-Pehrson G, Geard CR, Brenner DJ, Hall EJ. The bystander effect in radiation oncogenesis: I. Transformation in C3H 10T1/2 cells in vitro can be initiated in the unirradiated neighbors of irradiated cells. Radiat Res 2001;155(3):397-401.

18. Iyer R, Lehnert BE. Effects of ionizing radiation in targeted and nontargeted cells. Arch Biochem Biophys 2000;376(1):14-25.

19. Lehnert BE, Goodwin EH, Deshpande A. Extracellular factor(s) following exposure to alpha particles can cause sister chromatid exchanges in normal human cells. Cancer Res 1997;57(11):2164-71. 
20. Prise KM, Belyakov OV, Folkard M, Michael BD. Studies of bystander effects in human fibroblasts using a charged particle microbeam. Int J Radiat Biol 1998;74(6):793-8.

21. Huo L, Nagasawa H, Little JB. HPRT mutants induced in bystander cells by very low fluences of alpha particles result primarily from point mutations. Radiat Res 2001;156(5):521-5.

22. Schettino G, Folkard M, Prise KM, Vojnovic B, Held KD, Michael BD. Low-dose studies of bystander cell killing with targeted soft X rays. Radiat Res 2003;160(5):505-11.

23. Suchowerska N, Ebert MA, Zhang M, Jackson M. In vitro response of tumour cells to nonuniform irradiation. Phys Med Biol 2005;50(13):3041-51.

24. Mackonis EC, Suchowerska N, Zhang M, Ebert M, McKenzie DR, Jackson M. Cellular response to modulated radiation fields. Phys Med Biol 2007;21;52(18):5469-82.

25. Trainor C, Butterworth KT, McGarry CK, McMahon SJ, O'Sullivan JM, Hounsell AR, Prise KM. DNA damage responses following exposure to modulated radiation fields. PLoS One. 2012;7(8):e43326.

26. Belyakov OV, Folkard M, Mothersill C, Prise KM, Michael BD. A proliferation-dependent bystander effect in primary porcine and human urothelial explants in response to targeted irradiation. Br J Cancer 2003;88(5):767-74.

27. Belyakov OV, Folkard M, Mothersill C, Prise KM, Michael BD.Bystander-induced differentiation: a major response to targeted irradiation of a urothelial explant model. Mutat Res. 2006;11;597(1-2):43-9.

28. Belyakov OV, Mitchell SA, Parikh D, Randers-Pehrson G, Marino SA, Amundson SA, Geard CR, Brenner DJ. Biological effects in unirradiated human tissue induced by radiation damage up to 1 mm away. Proc Natl Acad Sci U S A 2005;102(40):14203-8. 
29. Sedelnikova OA, Nakamura A, Kovalchuk O, Koturbash I, Mitchell SA, Marino SA, Brenner DJ, Bonner WM. DNA double-strand breaks form in bystander cells after microbeam irradiation of three-dimensional human tissue models. Cancer Res. 2007;67(9):4295-302.

30. O'Dowd C, Mothersill CE, Cairns MT, Austin B, McClean B, Lyng FM, Murphy JE. The release of bystander factor(s) from tissue explant cultures of rainbow trout (Onchorhynchus mykiss) after exposure to gamma radiation. Radiat Res. 2006;166(4):611-7.

31. Sheridan J, Tosetto M, Gorman J, O'Donoghue D, Sheahan K, Hyland J, Mulcahy H, Gibbons D, O'Sullivan J. Effects of Radiation on Levels of DNA Damage in Normal Non-adjacent Mucosa from Colorectal Cancer Cases. J Gastrointest Cancer. 2012 Oct 14.

32. Chai Y, Hei TK. Radiation Induced Bystander Effect in vivo. Acta Med Nagasaki. 2008;53:S65S69.

33. Emerit I. Reactive oxygen species, chromosome mutation, and cancer: possible role of clastogenic factors in carcinogenesis. Free Radic Biol Med. 1994 Jan;16(1):99-109.

34. Lindholm C, Acheva A, Salomaa S. Clastogenic plasma factors: a short overview. Radiat Environ Biophys 2010;49(2):133-8.

35. Mole RH. Whole body irradiation; radiobiology or medicine? Br J Radiol. 1953;26(305):234

36. Camphausen K, Moses MA, Ménard C, Sproull M, Beecken WD, Folkman J, O'Reilly MS. Radiation abscopal antitumor effect is mediated through p53. Cancer Res 2003;63(8):1990-3.

37. Koturbash I, Rugo RE, Hendricks CA, Loree J, Thibault B, Kutanzi K, Pogribny I, Yanch JC, Engelward BP, Kovalchuk O. Irradiation induces DNA damage and modulates epigenetic effectors in distant bystander tissue in vivo. Oncogene 2006;25(31):4267-75.

38. Watson GE, Lorimore SA, Macdonald DA, Wright EG. Chromosomal instability in unirradiated cells induced in vivo by a bystander effect of ionizing radiation. Cancer Res 2000;15;60(20):5608-11. 
39. Xue LY, Butler NJ, Makrigiorgos GM, Adelstein SJ, Kassis AI. Bystander effect produced by radiolabeled tumor cells in vivo. Proc Natl Acad Sci U S A 2002;99(21):13765-70.

40. Ilnytskyy Y, Koturbash I, Kovalchuk O. Radiation-induced bystander effects in vivo are epigenetically regulated in a tissue-specific manner. Environ Mol Mutagen 2009;50(2):105-13.

41. Mancuso M, Pasquali E, Leonardi S, Tanori M, Rebessi S, Di Majo V, Pazzaglia S, Toni MP, Pimpinella M, Covelli V, Saran A. Oncogenic bystander radiation effects in Patched heterozygous mouse cerebellum. Proc Natl Acad Sci U S A 2008;105(34):12445-50.

42. Mancuso M, Giardullo P, Leonardi S, Pasquali E, Casciati A, De Stefano I, Tanori M, Pazzaglia S, Saran A. Dose and spatial effects in long-distance radiation signaling in vivo: implications for abscopal tumorigenesis. Int J Radiat Oncol Biol Phys 2013;85(3):813-9.

43. Rowitch DH, S-Jacques B, Lee SM, Flax JD, Snyder EY, McMahon AP. Sonic hedgehog regulates proliferation and inhibits differentiation of CNS precursor cells. J Neurosci 1999;19(20):8954-65.

44. Pazzaglia S, Tanori M, Mancuso M, Gessi M, Pasquali E, Leonardi S, Oliva MA, Rebessi S, Di Majo V, Covelli V, Giangaspero F, Saran A. Two-hit model for progression of medulloblastoma preneoplasia in Patched heterozygous mice. Oncogene 2006;25(40):5575-80.

45. Khan MA, Hill RP, Van Dyk J. Partial volume rat lung irradiation: an evaluation of early DNA damage. Int J Radiat Oncol Biol Phys 1998;40(2):467-76.

46. Khan MA, Van Dyk J, Yeung IW, Hill RP. Partial volume rat lung irradiation; assessment of early DNA damage in different lung regions and effect of radical scavengers. Radiother Oncol 2003;66(1):95-102

47. Mothersill C, Smith RW, Saroya R, Denbeigh J, Rowe B, Banevicius L, Timmins R, Moccia R, Seymour CB. Irradiation of rainbow trout at early life stages results in legacy effects in adults. Int J Radiat Biol 2010;86(10):817-28. 
48. Mothersill C, Smith RW, Fazzari J, McNeill F, Prestwich W, Seymour CB. Evidence for a physical component to the radiation-induced bystander effect? Int J Radiat Biol 2012;88(8):58391.

49. Mothersill C, Smith RW, Hinton TG, Aizawa K, Seymour CB. Communication of radiationinduced signals in vivo between DNA repair deficient and proficient medaka (Oryzias latipes). Environ Sci Technol 2009;43(9):3335-42.

50. Bertucci A, Pocock RD, Randers-Pehrson G, Brenner DJ. Microbeam irradiation of the C. elegans nematode. J Radiat Res 2009;50 Suppl A:A49-54.

51. Li F, Liu P, Wang T, Bian P, Wu Y, Wu L, Yu Z. The induction of bystander mutagenic effects in vivo by alpha-particle irradiation in whole Arabidopsis thaliana plants. Radiat Res 2010;174(2):228-37.

52. Verhaegen F, Granton P, Tryggestad E. Small animal radiotherapy research platforms. Phys Med Biol 2011;56(12):R55-83.

53. Brenner D, Little J, Sachs R.The bystander effect in radiation oncogenesis: II. A quantitative model. Radiat Res 2001;155(3)408: 402-408.

54. Little MP, Wakeford R. The bystander effect in C3H 10T cells and radon- induced lung cancer. Radiat Res 2001;156(6)156: 695-699.

55. Nikjoo H, Khvostunov IK. Biophysical model of the radiation-induced bystander effect. International Journal of Radiation Biology 2003;79(1): 43-52.

56. Little MP, Filipe J a N, Prise KM, Folkard M, Belyakov OV. A model for radiation-induced bystander effects, with allowance for spatial position and the effects of cell turnover. J Theor Biol 2005;232(3): 329-338

57. Stewart RD, Ratnayake RK, Jennings K. Microdosimetric model for the induction of cell killing through medium-borne signals. Radiat Res 2006;165(4):460- 469. 
58. Shuryak I, Sachs RK, Brenner DJ. Biophysical models of radiation bystander effects: 1. Spatial effects in three-dimensional tissues. Radiat Res 2007;168(6):741-749.

59. Fakir H, Hofmann W, Tan W. Triggering-response model for radiation- induced bystander effects. Radiat Res 2009;171(3)331:320-331.

60. Ebert M, Suchowerska N, Jackson M,McKenzie DR. A mathematical framework for separating the direct and bystander components of cellular radiation response. Acta Oncol 2010;49(9): 13341343.

61. McMahon SJ, Butterworth KT, Trainor C, McGarry CK, O'Sullivan JM, Schettino G, Hounsell AR, Prise KM. A kinetic-based model of radiation-induced intercellular signalling. PLoS One. 2013;8(1):e54526.

62. Bentzen SM. Theragnostic imaging for radiation oncology: dose-painting by numbers. Lancet Oncol. 2005;6(2):112-7.

63. Eidemüller M, Jacob P, Lane RS, Frost SE, Zablotska LB. Lung cancer mortality (1950-1999) among Eldorado uranium workers: a comparison of models of carcinogenesis and empirical excess risk models. PLoS One. 2012;7(8):e41431.

64. Newhauser, WD., Durante, M. Assessing the risk of second malignancies after modern radiotherapy. Nature Reviews Cancer 2011;11(6):438-448. 
Table 1

Summary of experimental approaches to study RIBEs using in vitro single cell models

\begin{tabular}{llll} 
Experimental system & Observed effects & Biological endpoint & Reference(s) \\
\hline $\begin{array}{l}\text { Low fluence } \alpha \text {-particle } \\
\text { Radiation microbeam }\end{array}$ & Bystander & Genomic instability & $(3)$ \\
& Clonogenic survival & $(22)$ \\
& & Cell survival & $(17)$ \\
Media transfer & Transformation & \\
Co-culture & Clonogenic survival & $(5,14,15)$ \\
& Micronuclei & $(6)$ \\
Modulated field & Bystander \& & DNA damage & \\
& cohort & Clonogenic survival & $(7,23,24)$
\end{tabular}

DNA damage

Table 2

Summary of experimental approaches to study RIBEs using ex vivo tissue models

\begin{tabular}{llll} 
Experimental system & Observed effects & Biological endpoint & Reference(s) \\
\hline Urothelial explant model & Bystander & Differentiation & $(26,27)$ \\
3D skin model & & MN, apoptosis & $(28,29)$ \\
Fish explant model & DSBs & \\
Human colon explant & Clonogenic survival & (30)
\end{tabular}

Table 3 
Summary of experimental approaches to study RIBEs using in vivo models

$\begin{array}{lllll}\text { Organism } & \text { Model system } & \text { Observed effects } & \text { Biological endpoint } & \text { Reference(s) } \\ \text { Mouse } & \text { CBA/H mouse } & \text { Bystander } & \text { Genomic instability } & (38) \\ & \text { NCr nude mice } & \text { Bystander } & \text { Tumour volume } & (39) \\ & & & 125 \text { IUdR labelling } & \\ & \text { C57BL/6 } & \text { Abscopal } & \text { Tumour growth } & (36) \\ \text { C57BL/6 \& } & \text { Abscopal } & \text { DNA damage } & (37) \\ & \text { BALB/c mice } & & \text { Proliferation } & \\ & & & \text { Apoptosis } & (40) \\ \text { C57BL/6 } & \text { Bystander } & \text { DNA methylation } & (41,42) \\ & \text { Ptch1 }{ }^{+/-} \text {mouse } & \text { Abscopal } & \text { Tumourigenesis } \\ \text { Rainbow trout } & \text { Bystander } & \text { Reporter assay } & (47) \\ \text { Zebrafish } & \text { Bystander } & \text { Reporter assay } & (48) \\ \text { Medaka } & \text { Bystander } & \text { Apoptosis } & (49) \\ \text { Rat } & \text { Abscopal } & \text { Abscopal } & \text { DNA damage } & (45,46) \\ & \text { C. elegans } & \text { Abscopal } & \text { hsp GFP reporter } & (50) \\ & & \text { DNA damage } & (51)\end{array}$




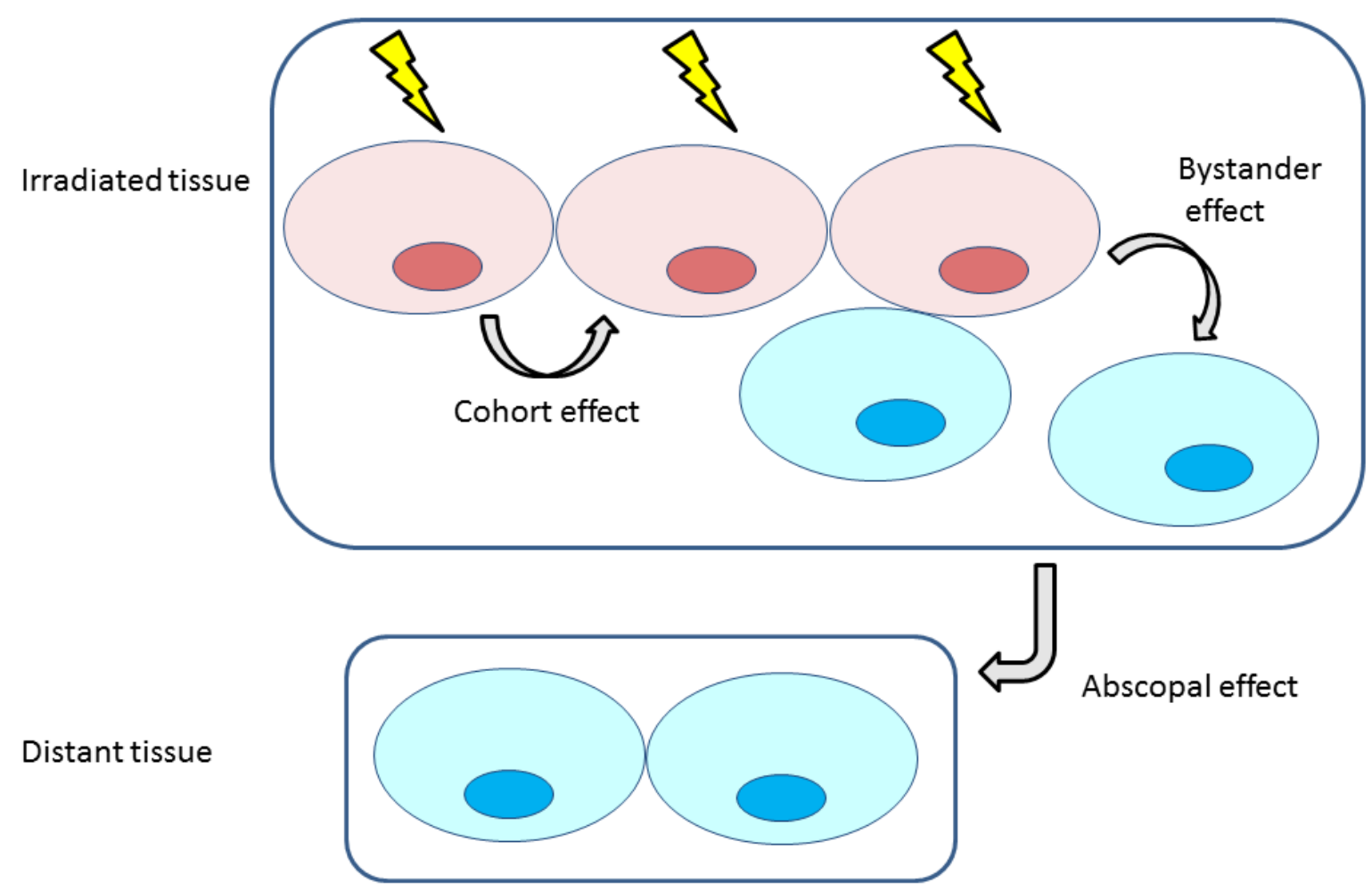

\section{Figure 1}

Schematic representation of radiation induced signalling effects classified by Blyth and Sykes (8). Irradiated cells are shown in red; unirradiated cells in blue. Bystander effects occur in unirradiated cells within an irradiated volume; within the same volume, radiation induced signalling contributes to the overall response through cohort effects. Abscopal effects occur in unirradiated tissue at a distant site outside of an irradiated volume 
a) Radiation microbeam
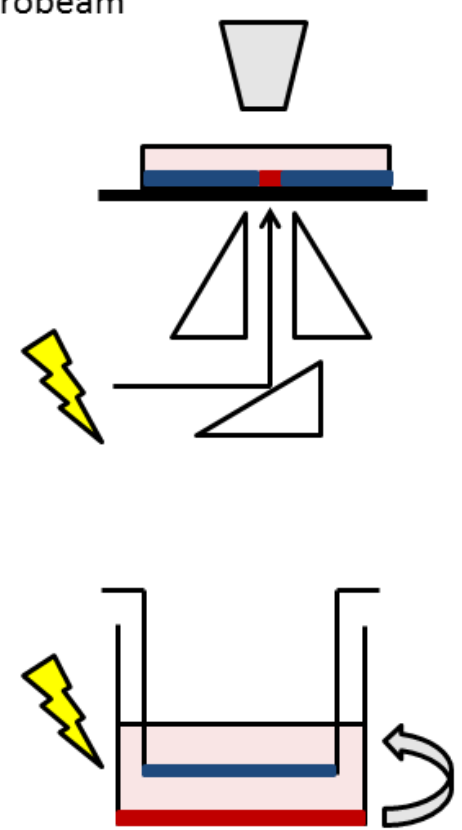

c) Cell co-culture b) Medium transfer
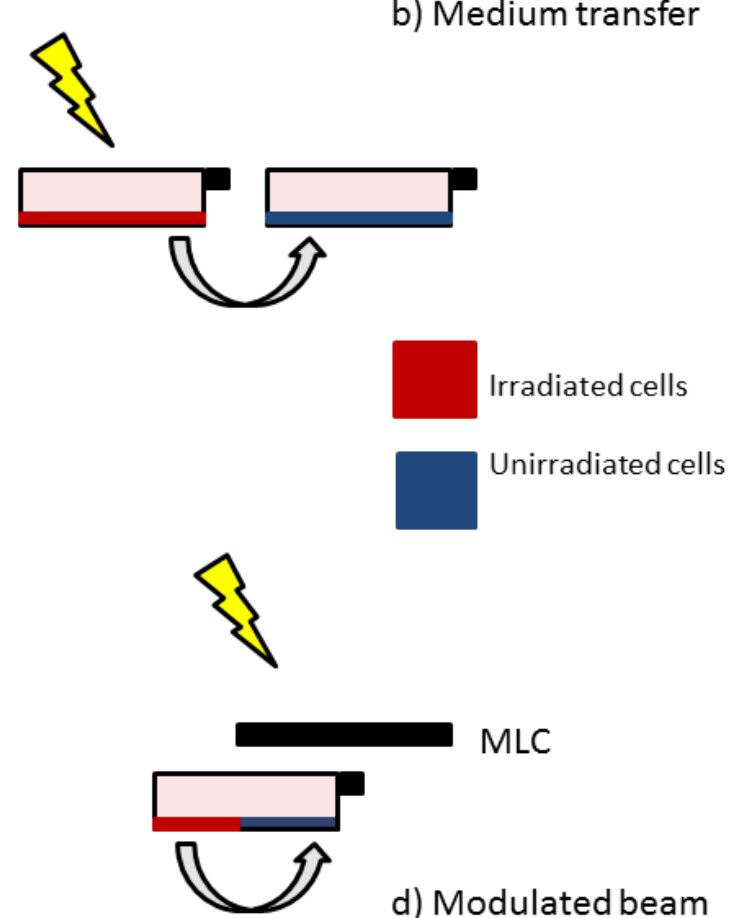

d) Modulated beam

\section{Figure 2}

Schematic representation of experimental approaches for investigating radiation induced signalling effects in vitro using single cell models. a) Radiation microbeams are used to target single cells or subcellular components within cell populations. b) Irradiated cell conditioned medium is transferred to unirradiated recipient cells from irradiated donor cells. c) Irradiated cells are co-cultured with unirradiated using a cell insert system. d) Modulated fields are created using a multi-leaf collimator (MLC) to place cells out-of-field. 